\title{
HGFAC wt Allele
}

National Cancer Institute

\section{Source}

National Cancer Institute. HGFAC wt Allele. NCI Thesaurus. Code C127007.

Human HGFAC wild-type allele is located in the vicinity of $4 p 16$ and is approximately $8 \mathrm{~kb}$ in length. This allele, which encodes hepatocyte growth factor activator protein, plays a role in the activation of hepatocyte growth factor. 